\title{
THE AMITRAZ STRIPS EFFICACY IN CONTROL OF VARROA DESTRUCTOR AFTER MANY YEARS APPLICATION OF AMITRAZ IN APIARIES
}

\author{
Piotr Semkiw ${ }^{1 *}$, Piotr Skubida ${ }^{1}$, Krystyna Pohorecka ${ }^{2}$
}

\author{
${ }^{1}$ Research Institute of Horticulture, Apiculture Division, Puławy, Poland \\ ${ }^{2}$ National Veterinary Research Institute, Department of Honey Bee Diseases, Puławy, Poland \\ *corresponding author: piotr.semkiw@man.pulawy.pl
}

Received 26 April 2013; accepted 14 May 2013

$\mathrm{S}$ u m m a r y

\begin{abstract}
Amitraz is a varroacide used the longest (over thirty years) and most commonly by Polish beekeepers. This involves high risk of $V$. destructor developing amitraz resistance. Therefore it is necessary to monitor the effectiveness of treatments to ensure appropriate protection of the honeybee colonies. The objective of this study was to evaluate the efficacy of amitraz used as the contact varroacide (Biowar 500 formulation) to control $V$. destructor in honeybee colonies. Field studies were conducted in 2011 and 2012. In both years, the amitraz treatments started in the last weeks of August. Two strips of Biowar 500 (500 mg of amitraz per strip) were inserted into each colony and removed after 8 weeks. The control colonies were left untreated for 8 weeks. After removing the strips the control therapy was conducted in all colonies. The average efficacy of amitraz $(\mathrm{E} \%)$ calculated for the two years combined, after 6 and 8 weeks of treatment, amounted to $90.6 \%$ and $94.6 \%$, respectively. As a result of the natural mortality in the control colonies, the population of parasites lowered only by $16.4 \%$ and $23.9 \%$ during 6 and 8 weeks. The efficacy of the strips was lower in colonies with larger amount of brood.
\end{abstract}

Keywords: Varroa destructor, control, honeybee colonies, amitraz strips, effectiveness.

\section{INTRODUCTION}

Over several decades, the infestation of the ectoparasitic mite $V$. destructor (Anderson and Trueman, 2000) has been the dominant problem of beekeeping worldwide. The destructive impact of the Varroa mite on honeybees (Apis mellifera) has become particularly apparent in the last few years when a significant increase in managed colonies mortality and global declines of honeybee populations have been noted (Potts et al., 2010). The recent research proved that $V$. destructor contributes the most to the honeybee losses in many countries (Brodschneider et al., 2010; Chauzat et al., 2010; Dahle, 2010; Genersch et al., 2010; GuzmánNovoa et al., 2010; Le Conte et al., 2010; Schäfer et al., 2010; Topolska et al., 2010; Pohorecka et al., 2011; van Engelsdorp et al., 2011; Martin et al., 2012; Nazzi et al., 2012). Thus, fighting these mites is still a priority in beekeeping management (Delaplane, 2011).

Without treatment or with incorrect therapy, honeybee colonies die within one to three years. However, none of the varroacides guarantees complete elimination of the parasite's population in the honeybee colonies. The lack of $100 \%$ effective miticides combined with the high pathogenicity of the $V$. destructor as well as the mite's fast population growth and rapid spread, force the beekeepers to use varroacides even up to several times a year (Boecking and Genersch, 2008; Genersch, 2010; Rosenkranz et al., 2010). This, in turn, leads to the accumulation of the therapeutic agent residues in the hive environment (Lodesani et al., 1992; Bogdanov and Kilchenmann, 1995; Bogdanov 
et al., 1998; Wallner, 1999) and to the development of Varroa mite resistance to these compounds (Lodesani et al., 1995; Milani, 1999; Floris et al., 2001; Spreafico et al., 2001).

Varroacides, predominatly used to control the $V$. destructor infestation, are synthetic pesticides including: taufluvalinat, flumethrin, coumaphos, and amitraz. Amitraz (formamidine pesticide) was one of the first chemicals tested for the control of the Varroa mite population, with studies dating back to 1979 (Merrington, 1990). Amitraz acts on the target pest species interacting with the octopamine receptor of the central nervous system and is known as neurotoxic, sub-lethal miticide (Evans and Gee, 1980). Paralyzed Varroa mites fall onto the bottom boards of hives and die of starvation. Amitraz is a fat-soluble compound, but it is unstable and hydrolyzes in a short time (Jimenez et al., 1997). Amitraz degradation products are 2,4-dimethylaniline (DMA), 2,4-dim e thy l phen y 1 form a m ide (DMF) and N-(2,4-dimethylphenyl)-N' methylformamidine (DMPF) (Korta et al., 2001). Amitraz residues are rarely found in honey. In beeswax, however, amitraz itself or its metabolite (DMA, DMPF) have been detected (Lodesani et al., 1992; Martel et al., 2007; Johnson et al., 2010; Mullin et al., 2010).

Amitraz is widely used in Europe (Portugal, Ireland, Italy, Belgium, Turkey, and France) as the French formulation Apivar. It is also registered in New Zealand and Canada. Amitraz was one of the first varroacides to be registered in the USA under the trade name Miticur. However, in 1994 the preparation was withdrawn from the market (Johnson et al., 2013). Now amitraz is reregistered in some states of the U.S.

After many years of using amitraz, the Varroa mites have developed resistance to this substance. Amitraz was found to be ineffective in killing mites in the former Yugoslavia (Dujin et al., 1991). The mites populations resistance to amitraz was also confirmed in the USA, Italy, Portugal,
Argentina, and France (Elzen et al, 1999; Milani, 1999; Elzen et al., 2000; Mathieu and Faucon, 2000; Pires et al., 2005; 2007; Maggi et al., 2010).

The Commission Regulation (EU) No $37 / 2010$ permits the use of amitraz in beekeeping in the European Union Member States. The maximum residue limits for amitraz (MRL) in honey has been establishment at $200 \mu \mathrm{g} / \mathrm{kg}$ honey. On 20 March 2013, the U.S. Environmental Protection Agency (EPA) published a final rule (78 FR 17123) amending the MRL regulations for amitraz. New MRL for amitraz, including its metabolites and degradates, amounts to $200 \mu \mathrm{g} / \mathrm{kg}$ in honey and $9000 \mu \mathrm{g} / \mathrm{kg}$ in honeycomb.

Amitraz is a varroacide used the longest and most commonly by Polish beekeepers. Since 1984, when it was registered in Poland for the first time, this compound has been hitherto continuously applied under the trade name Apiwarol. The formulation contains $12.5 \mathrm{mg}$ of the active ingredient in one smoking tablet and is suitable for bee colony fumigations. A single treatment takes approximately 20 minutes and should be repeated 2-3 times. From 2004 to 2008, amitraz was also available as the veterinary miticide Biowar. This product had $400 \mathrm{mg}$ of the active substance incorporated in a plastic strip. However, Biowar's disappointing efficacy resulted in the withdrawal of this product (Pohorecka et al., 2006; Chuda-Mickiewicz et al., 2007). In 2010, the new formulation Biowar 500 (manufactured by Biowet-Puławy, Poland) with the amitraz content increased to $500 \mathrm{mg}$ per strip, was registered. Amitraz is spread within the colony as a result of contact between the honey bees and the strips. It is recommended to place two strips in each hive for 6 to 8 weeks (also when the brood is present in the colony). During that time the strips release amitraz. This way the treatment lasts for several reproduction cycles of the Varroa mite enabling a more effective way to get rid of parasites.

Amitraz has been frequently used in Polish apiaries for thirty years. This means there is a high risk of the $V$. destructor 
populations developing resistant to amitraz. Therefore, it is necessary to monitor the effectiveness of treatments to ensure appropriate protection of the honeybee colonies.

The objective of the research presented in this paper was to evaluate the efficacy of amitraz used as the contact varroacide (Biowar 500 formulation) to control $V$. destructor in the honeybee colonies.

\section{MATERIAL AND METHODS}

Field studies were conducted in 2011 and 2012, in the apiary of the Research Institute of Horticulture, Apicultural Division in Puławy, Poland. The studies were conducted according to the "Technical Guidelines for the Evaluation of Treatments for Control of Varroa Mites in Honey Bee Colonies. Recommendations from the CA 3686" (Commission of the European Communities, 2002).

\section{Honeybee colonies}

The colonies of Apis mellifera caucasica were used in the experiment. The colonies were settled in the Wielkopolski hives (frame size: $360 \mathrm{~mm}$ x $260 \mathrm{~mm}$ ) equipped with deep bottom boards covered with mesh. The bottom boards had drawers enabling to monitor the numbers of dead Varroa destructor specimens.

The colonies strength was assessed before the study (bees and brood population). It was done to establish a homogenous experimental group (treated) and the control group (untreated).

The population of adult bees was assessed by counting the number of combs with both sides covered by bees. To estimate the amount of brood (opened and capped brood), vertical and horizontal axes of brood combs were measured on each side of the brood combs. To calculate the area $\left(\mathrm{dm}^{2}\right)$, "Tables of Brood Area Measurements" from the Polish Industry Standard (BN-81/9148-01, 1982) were used.

The efficacy of amitraz in fighting the Varroa mite was assessed in 89 experimental colonies (44 colonies in 2011 and 45 in 2012). The natural mortality of the parasite was assessed in 2011, in the 10 control colonies (untreated).

The population size (bees and brood) of each experimental and control colony was also assessed 3 and 6 weeks from the beginning of the experiment.

Before the experiment took place $V$. destructor population in the experimental colonies was controlled with the veterinary miticides containing flumethrin (Bayvarol) or amitraz (Biowar strips or Apiwarol fumigations).

Amitraz treatment and efficacy assay

In both years, the amitraz treatments were started in the last weeks of August. Two strips of Biowar $500(500 \mathrm{mg}$ of amitraz per strip) were inserted into each colony. The strips were inserted into the inter-frame spaces (extended to $16 \mathrm{~mm}$ ) at both sides of the chamber brood. The strips were placed centrally between two last brood combs.

The strips were removed after 8 weeks, in the third decade of October. The control colonies were left untreated for 8 weeks. The dead parasites that fell onto the bottom boards in the experimental and control colonies were counted every 7 days. After removing the strips, the control therapy was conducted in all colonies. It was done to assess the number of mites that survived the treatment with Biowar 500.

Colonies were fumigated with Apiwarol (12.5 mg amitraz/tablet) two times every 7 days (dosage: 1 tablet/treatment/colony). In the period when no brood was present in the hives, i.e. in the first week of November, the second control preparation was used. Into the beeways of every colony $5 \mathrm{ml}$ of $3.5 \%$ oxalic acid solution was trickled.

The dead parasites that fell onto the bottom boards were counted after 7 days from applying each control treatment.

Two parameters were used to assess the amitraz treatment's efficacy. The first one was the percent efficacy (E\%) calculated as:

$$
\mathrm{E} \%=100\left[\mathrm{~T}_{\mathrm{B}} /\left(\mathrm{T}_{\mathrm{C}}+\mathrm{T}_{\mathrm{B}}\right)\right]
$$

where $T_{B}=$ the total number of mites fallen at the bottom board of each treated hive during the treatment period and 
$\mathrm{T}_{\mathrm{C}}=$ the number of mites collected after the final treatments. E\% was calculated for the six- and eight-week treatment periods.

The second was the corrected efficacy $\%(\mathrm{C} \%)$ according to Abbott (1925), calculated as:

$$
\text { Corrected } \%=\left(1-\frac{\mathrm{n} \text { in T after treatment }}{\mathrm{n} \text { in Co after treatment }}\right) * 100
$$

where $: \mathrm{n}=$ mite's population, $\mathrm{T}=$ treated, $\mathrm{Co}=$ the control.

\section{Statistical analysis}

The results were statistically analyzed with the STATISTICA 10 software. The parameters were compared using nonparametric tests due to the distribution of data. Depending on the number of analyzed groups, the Mann-Whitney U test or Kruskal-Wallis test were used. The differences were considered statistically significant with $\mathrm{p}$ values $\leq 0.05$. The correlation between variables was assessed using Spearman's rank correlation coefficient.

\section{RESULTS}

In both years, the colonies had similar strength at the time of inserting the Biowar 500 strips (Tab. 1). After 3 weeks of treatment, the colonies strength declined considerably with reference to both parameters (number of combs covered by bees: $\mathrm{H}_{5,267}=210.28, \mathrm{p}=0.000$; brood area: $\mathrm{H}_{5,267}=174.74, \mathrm{p}=0.000$ ). After 6 weeks of treatment, the colonies condition did not change in relation to the assessment made 3 weeks earlier.

At every measurement date, the number of combs covered by bees and the amount of reared brood in the control colonies were similar to the experimental colonies (Tab. 2). After 3 weeks of treatment, the strength of the control colonies significantly decreased with relation to both parameters number of combs covered by bees: $\mathrm{H}_{5,297}=222.95, \mathrm{p}=0.000$; the brood area: $\mathrm{H}_{5,297}=193.23, \mathrm{p}=0.000$ ). The differences in the numbers of combs covered by bees and the brood area between the second and the third measurement were not statistically significant.

In both years, the level of $V$. destructor infestation differed significantly (Tab. 3). In the group of colonies treated with amitraz, the infestation levels ranged from 101 to 4463 mites. In 2011, the average number of $V$. destructor was $550.1 \mathrm{mites} /$ colony and was significantly higher $\left(\mathrm{U}_{44,45}=602.5, \mathrm{p}=0.001\right)$ than in 2012 (on average, 436 mites/colony). The number of parasites in the colony was positively correlated with the amount of reared brood $\left(r_{s}=0.93, d f=43, p=0.008\right.$ and $r_{s}=0.82$, df $=44, p=0.006$, for 2011 and 2012 , respectively).

During the 8 weeks of the colonies exposure to Biowar 500 strips, an average of 532.5 parasites was found in 2011, and 410.7 in $2012\left(\mathrm{U}_{44,45}=585, \mathrm{p}=0.0007\right)$.

Table 1 .

Biological status of the experimental (treated) bee colonies

\begin{tabular}{|c|c|c|c|c|c|c|}
\hline \multirow{2}{*}{ Year } & \multirow{2}{*}{$\begin{array}{l}\text { Number of } \\
\text { bee colonies } \\
\text { (n) }\end{array}$} & \multirow{2}{*}{$\begin{array}{l}\text { Measurement } \\
\text { time }\end{array}$} & \multicolumn{2}{|c|}{$\begin{array}{l}\text { Number of combs } \\
\text { covered by bees }\end{array}$} & \multicolumn{2}{|c|}{ Brood area $\left(\mathrm{dm}^{2}\right)$} \\
\hline & & & $\begin{array}{c}\text { Range } \\
\text { (min-max) }\end{array}$ & Average $\pm \mathrm{SD}$ & $\begin{array}{c}\text { Range } \\
(\min -\text { max })\end{array}$ & Average \pm SD \\
\hline \multirow{3}{*}{2011} & \multirow{3}{*}{44} & Pre treatment & $10-19$ & $15.5 b^{*} \pm 1.6$ & $23.2-68.6$ & $49.0 \mathrm{~b} \pm 9.7$ \\
\hline & & $\begin{array}{c}\text { After } 3 \text { weeks } \\
\text { of treatment }\end{array}$ & $6-9$ & $8.7 a \pm 0.7$ & $0-17.6$ & $4.8 \mathrm{a} \pm 4.0$ \\
\hline & & $\begin{array}{c}\text { After } 6 \text { weeks } \\
\text { of treatment }\end{array}$ & $6-9$ & $8.5 a \pm 0.8$ & $0-17.5$ & $6.5 a \pm 3.9$ \\
\hline \multirow{3}{*}{2012} & \multirow{3}{*}{45} & Pre treatment & $10-18$ & $15.7 b \pm 1.6$ & $1.1-97.0$ & $43.2 \mathrm{~b} \pm 14.6$ \\
\hline & & $\begin{array}{c}\text { After } 3 \text { weeks } \\
\text { of treatment }\end{array}$ & $8-9$ & $8.7 a \pm 0.4$ & $0.2-18.4$ & $5.9 a \pm 4.4$ \\
\hline & & $\begin{array}{c}\text { After } 6 \text { weeks } \\
\text { of treatment }\end{array}$ & $6-9$ & $7.9 a \pm 0.7$ & $0-11.7$ & $4.7 a \pm 2.7$ \\
\hline
\end{tabular}

*The different letters in columns indicate significant differences between means (Kruskal - Wallis test, $\mathrm{p}<0.05$ ). 
Biological status of the experimental (treated) and the control (untreated) bee colonies

\begin{tabular}{||c|c|c|c|c|c|c||}
\hline \multirow{2}{*}{ Group } & \multirow{2}{*}{$\begin{array}{c}\text { Number of } \\
\text { bee colonies } \\
(\mathrm{n})\end{array}$} & & \multicolumn{2}{|c|}{$\begin{array}{c}\text { Number of combs } \\
\text { covered by bees }\end{array}$} & \multicolumn{2}{c||}{ Brood area $\left(\mathrm{dm}^{2}\right)$} \\
\cline { 3 - 7 } & & & $\begin{array}{c}\text { Range } \\
(\mathrm{min}-\mathrm{max})\end{array}$ & Average $\pm \mathrm{SD}$ & $\begin{array}{c}\text { Range } \\
(\mathrm{min}-\mathrm{max})\end{array}$ & Average $\pm \mathrm{SD}$ \\
\hline \multirow{2}{*}{$\begin{array}{c}\text { Experimental } \\
\text { (treated) }\end{array}$} & \multirow{2}{*}{89} & Pre treatment & $10-19$ & $15.6 \mathrm{~b}^{*} \pm 1.6$ & $1.1-97.0$ & $46.0 \mathrm{~b} \pm 12.7$ \\
\cline { 3 - 7 } & & After 3 weeks of treatment & $6-9$ & $8.7 \mathrm{a} \pm 0.6$ & $0-18.4$ & $5.4 \mathrm{a} \pm 4.2$ \\
\cline { 3 - 7 } & After 6 weeks of treatment & $6-9$ & $8.2 \mathrm{a} \pm 0.8$ & $0-17.6$ & $5.6 \mathrm{a} \pm 3.5$ \\
\hline \multirow{2}{*}{$\begin{array}{c}\text { Control } \\
\text { (untreated) }\end{array}$} & \multirow{2}{*}{10} & Pre treatment & $10-19$ & $15.9 \mathrm{~b} \pm 3.2$ & $38.7-69.8$ & $51.1 \mathrm{~b} \pm 10.5$ \\
\cline { 3 - 7 } & & After 3 weeks of treatment & $6-9$ & $8.3 \mathrm{a} \pm 0.9$ & $0.4-7.1$ & $4.1 \mathrm{a} \pm 2.2$ \\
\cline { 3 - 7 } & After 6 weeks of treatment & $6-9$ & $8.1 \mathrm{a} \pm 1.4$ & $0-8.1$ & $8.1 \mathrm{a} \pm 4.1$ \\
\hline
\end{tabular}

*The different letters in columns indicate significant differences between means (Kruskal - Wallis test, $\mathrm{p}<0.05)$.

Table 3 .

The numbers of $V$. destructor mites fallen

during the treatments in the experimental honeybee colonies

\begin{tabular}{|c|c|c|c|c|c|c|c|}
\hline \multirow{2}{*}{ Year } & \multirow{2}{*}{$\begin{array}{c}\begin{array}{c}\text { Number } \\
\text { of bee } \\
\text { colonies } \\
\text { (n) }\end{array} \\
\end{array}$} & \multirow{2}{*}{ Value } & \multirow{2}{*}{$\begin{array}{l}\text { The number of } \\
\text { fallen mites during } \\
\text { 8-week treatment } \\
\text { with Biowar } 500\end{array}$} & \multicolumn{3}{|c|}{$\begin{array}{l}\text { The number of fallen mites after } \\
\text { the control treatments }\end{array}$} & \multirow{2}{*}{$\begin{array}{l}\text { The total number } \\
\text { of fallen mites }\end{array}$} \\
\hline & & & & $\begin{array}{l}\text { Twice fumigation } \\
\text { with amitraz }\end{array}$ & $\begin{array}{l}3.5 \% \mathrm{OA}^{* *} \\
\text { solution }\end{array}$ & Total & \\
\hline \multirow[t]{2}{*}{2011} & & $\begin{array}{c}\text { Range } \\
(\text { min-max })\end{array}$ & $109-1654$ & $0-107$ & $0-23$ & $0-107$ & $115-1659$ \\
\hline & & Average \pm SD & $532.6 b^{\star} \pm 368.3$ & $15.3 a \pm 22.3$ & $2.3 a \pm 4$ & $17.5 a \pm 23.9$ & $550.1 b \pm 376.1$ \\
\hline \multirow[t]{2}{*}{2012} & \multirow{2}{*}{5} & $\begin{array}{c}\text { Range } \\
(\text { min-max })\end{array}$ & 3 & 13 & $0-36$ & $0-213$ & $101-4463$ \\
\hline & & Average \pm SD & $410.7 \mathrm{a} \pm 655.9$ & $22.5 \mathrm{a} \pm 35.8$ & $2.9 \mathrm{a} \pm 6.7$ & $25.3 a \pm 39$ & $436 a \pm 692$ \\
\hline
\end{tabular}

*The different letters in columns indicate significant differences between means

(Mann-Whitney U test, $\mathrm{p}<0.05$ ).

** oxalic acid

Table 4 .

The numbers of $V$. destructor mites fallen during

all treatments in the experimental and the control honeybee colonies

\begin{tabular}{||c|c|c|c|c|c||}
\hline Group & $\begin{array}{c}\text { Number } \\
\text { of bee } \\
\text { colonies } \\
(\mathrm{n})\end{array}$ & Value & $\begin{array}{c}\text { The number } \\
\text { of fallen mites } \\
\text { during 8-week } \\
\text { treatment }\end{array}$ & $\begin{array}{c}\text { The number } \\
\text { of fallen mites } \\
\text { after the control } \\
\text { treatments }\end{array}$ & $\begin{array}{c}\text { The total number } \\
\text { of mites in bee } \\
\text { colonies }\end{array}$ \\
\hline $\begin{array}{c}\text { Experimental } \\
\text { (treated) }\end{array}$ & 89 & $\begin{array}{c}\text { Range } \\
\text { (min - max) }\end{array}$ & $34-4323$ & $0-213$ & $101-4463$ \\
\cline { 3 - 6 } & Average \pm SD & $470.9 \mathrm{~b}^{*} \pm 540.1$ & $21.5 \mathrm{a} \pm 32.5$ & $492.4 \mathrm{a} \pm 558.4$ \\
\hline $\begin{array}{c}\text { The control } \\
\text { (untreated) }\end{array}$ & 10 & $\begin{array}{c}\text { Range } \\
\text { (min - max) }\end{array}$ & $40-1859$ & $274-1442$ & $334-2309$ \\
\cline { 3 - 6 } & Average $\pm \mathrm{SD}$ & $318.8 \mathrm{a} \pm 546.8$ & $701.8 \mathrm{~b} \pm 403.6$ & $1020.6 \mathrm{~b} \pm 638.7$ \\
\hline
\end{tabular}

*The different letters in columns indicate significant differences between means (Mann-Whitney U test, $\mathrm{p}<0.05)$.

** in the control group, the period of natural mite mortality. 


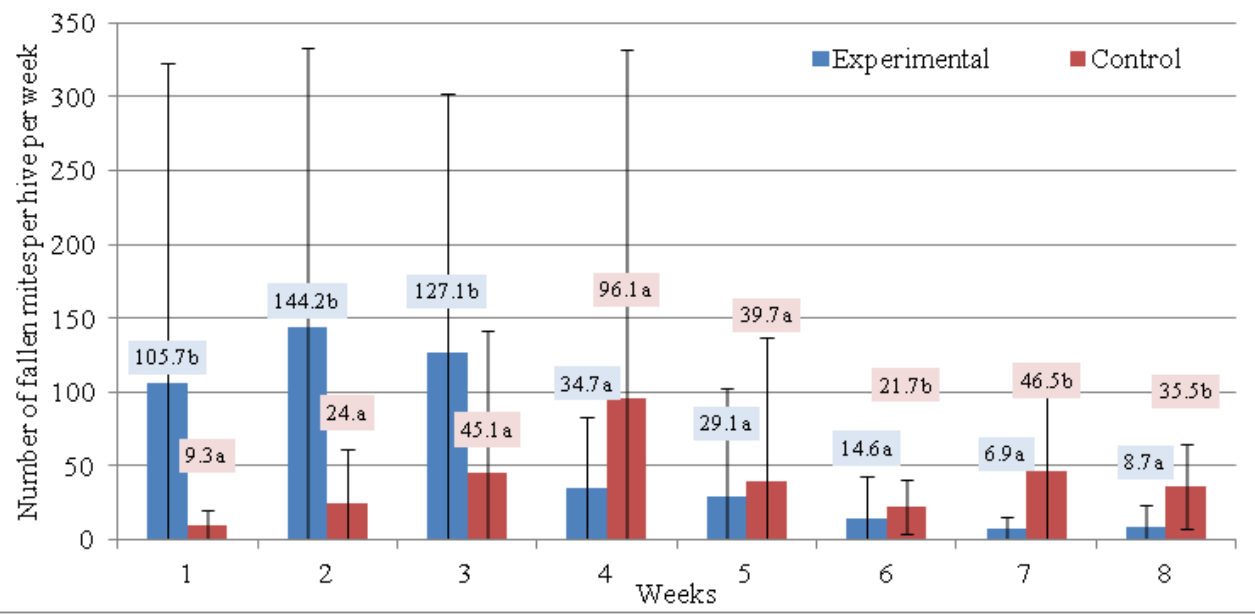

Fig. 1. Weekly average number of fallen mites in the experimental (treated) and the control (untreated) colonies (total for 2011 and 2012). Within each date, different letters indicate significant differences among treatments (Mann-Whitney $U$ test, $\mathrm{p}<0.05$ ). Bars indicate standard deviation.

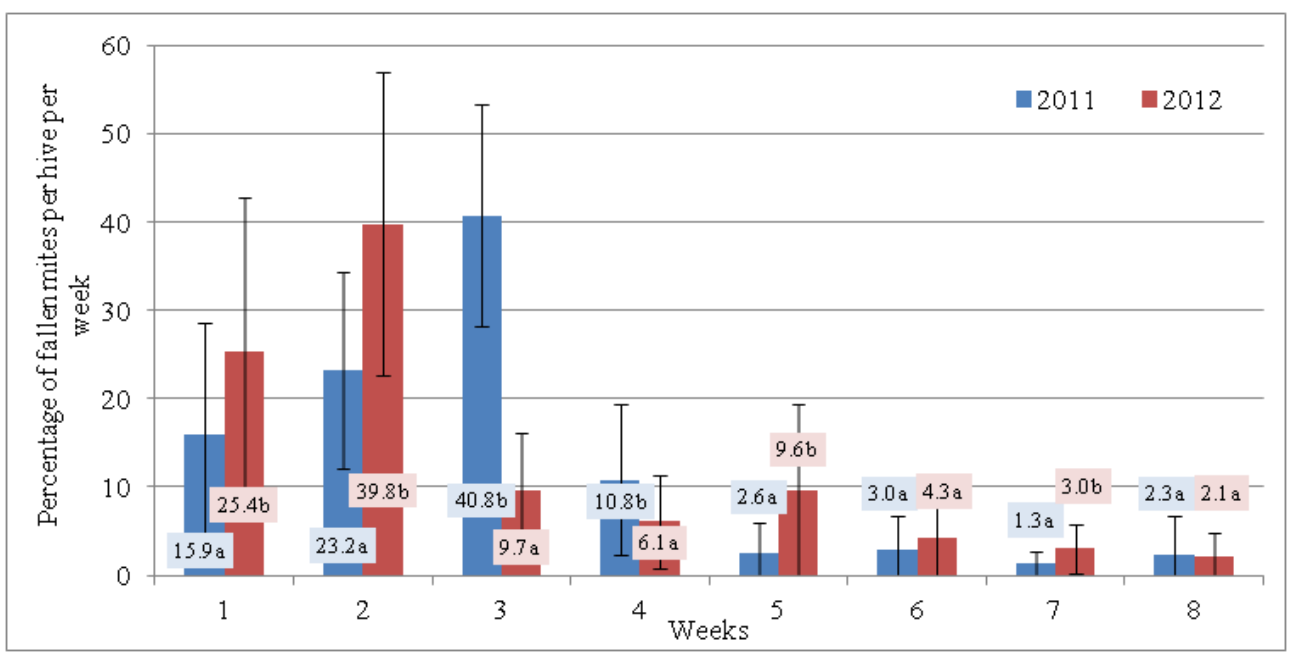

Fig. 2. Dynamics of the average weekly percentage of fallen mites in the experimental (treated) honeybee colonies in 2011 and 2012. Within each date, different letters indicate significant differences among treatments (Mann-Whitney $U$ test, $\mathrm{p}<0.05$ ). Bars indicate standard deviation.

Whereas the numbers of parasites that fell onto the bottom boards after the control treatments were similar in both years $\left(\mathrm{U}_{44,45}=812, \mathrm{p}=0.14\right)$. Most of the mites that survived the treatment with Biowar 500 had died after using the first control preparation (Apiwarol).

In the control colonies (untreated), the level of infestation with mites was significantly higher $\left(\mathrm{U}_{89.10}=585\right.$, $\mathrm{p}=0.001)$ and averaged 1020.6 parasites
(Tab. 4). After 8 weeks, as a result of natural mortality, significantly fewer mites $\left(\mathrm{U}_{89,10}=222.5, \mathrm{p}=0.009\right)$ had died in these colonies in comparison to the number of parasites that died in the colonies treated with Biowar 500 (on average, 318.8 and 470.9 dead mites/colony, respectively). After the control treatments, on average, 701.8 parasites had died in the untreated colonies and 21.5 in the experimental (treated) colonies $\left(\mathrm{U}_{89,10}=0.00, \mathrm{p}=0.0000\right)$. 


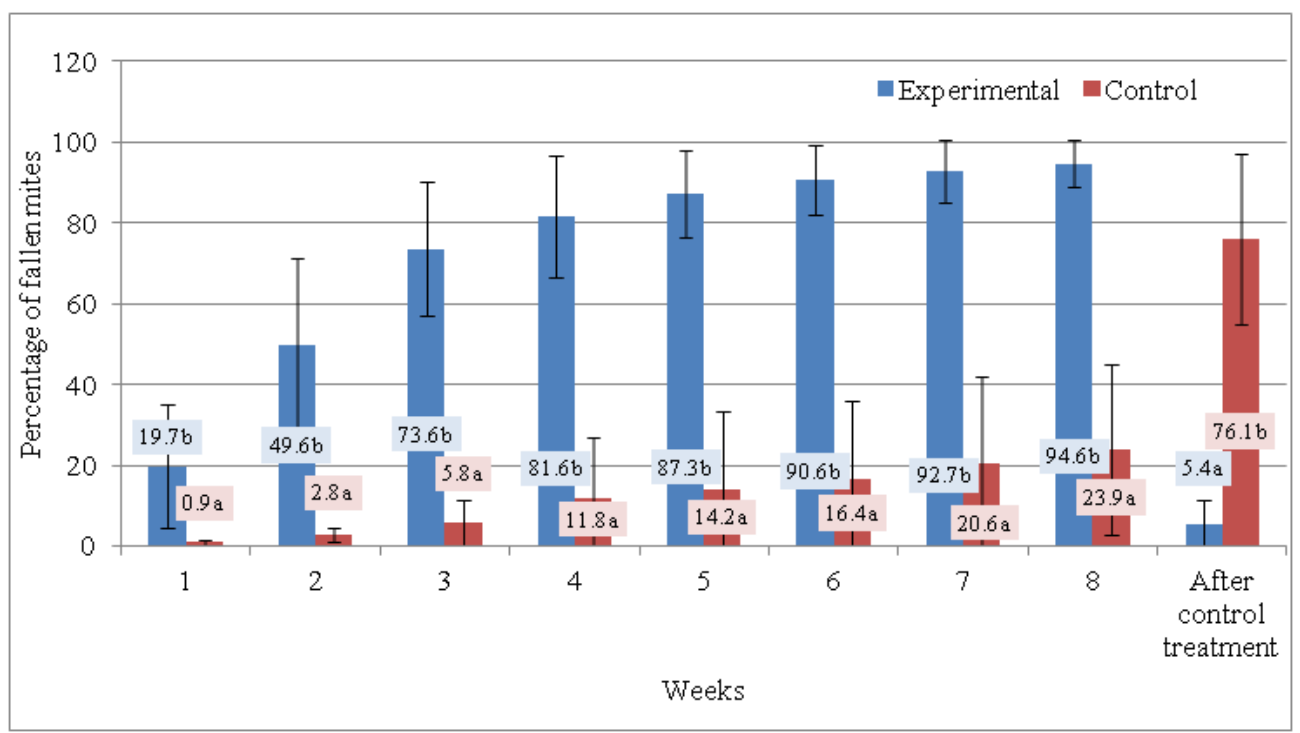

Fig. 3. The average weekly percentages of fallen mites in the experimental (treated) and the control (untreated) honeybee colonies (total numbers for 2011 and 2012). Within each date, different letters indicate significant differences among treatments (Mann-Whitney U test, $\mathrm{p}<0.05$ ). Bars indicate standard deviation.

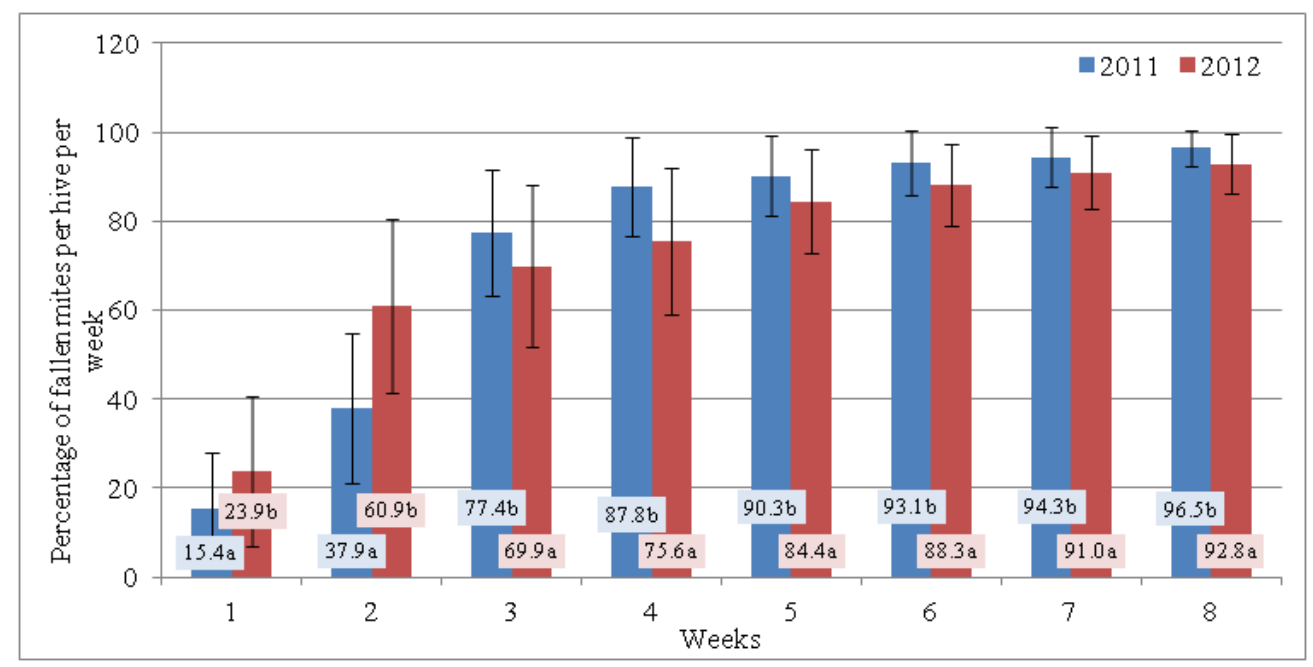

Fig. 4. Comparison of the average weekly treatment efficacy in the experimental honeybee colonies, in 2011 and 2012. Within each date, different letters indicate significant differences among treatments (Mann-Whitney U test, $\mathrm{p}<0.05$ ). Bars indicate standard deviation.

The dynamics of the number of dead mites after using amitraz was the highest in the first 3 weeks after placing the Biowar 500 strips in the hives (Fig. 1). During that time, on average, 377 mites had died, i.e. $80 \%$ of the total number of dead mites during the 8 -week treatment.
During the same time, the number of mites that died due to the natural mortality in the control colonies was significantly lower. It constituted $24.9 \%$ of the total number of parasites that died before applying the control treatment. During the next 2 weeks, the number of dead parasites did not differ 
Table 5 .

The amitraz treatment's efficacy against $V$. destructor evaluated by two different methods: $E \%=100\left[\mathrm{~T}_{\mathrm{B}} /\left(\mathrm{T}_{\mathrm{C}}+\mathrm{T}_{\mathrm{B}}\right)\right]$ where $\mathrm{T}_{\mathrm{B}}=$ the number of mites collected in each treated hive during the treatment period and $\mathrm{T}_{\mathrm{C}}=$ the number of mites collected after the final treatments;

$C \%=(1-\mathrm{n}$ in T after treatment $/ \mathrm{n}$ in Co after treatment $) * 100$ where $\mathrm{n}=$ mite's population, $\mathrm{T}=$ treated, $\mathrm{Co}=$ control

\begin{tabular}{||c|c|c|c|c|c|c||}
\hline \multirow{2}{*}{ Year } & \multirow{2}{*}{$\begin{array}{c}\text { Number } \\
\text { of bee } \\
\text { colonies } \\
(\mathrm{n})\end{array}$} & \multirow{2}{*}{$\begin{array}{l}\text { Weeks of } \\
\text { treatment }\end{array}$} & $\begin{array}{c}\text { Range } \\
\text { (min - max })\end{array}$ & Average \pm SD & $\begin{array}{c}\text { Range } \\
(\text { min - max })\end{array}$ & Average \pm SD \\
\hline 2011 & \multirow{2}{*}{44} & 6 & $67.4-100$ & $93.1 \mathrm{~b}^{*} \pm 7.3$ & $75.5-100$ & $95.2 \mathrm{ab} \pm 5.8$ \\
\cline { 3 - 7 } & 8 & $79.7-100$ & $96.5 \mathrm{c} \pm 4$ & $84.7-100$ & $97.5 \mathrm{~b} \pm 3.4$ \\
\hline \multirow{2}{*}{2012} & \multirow{2}{*}{45} & 6 & $58.5-98.9$ & $88.3 \mathrm{a} \pm 9.2$ & $54.8-99.5$ & $94.2 \mathrm{a} \pm 5.6$ \\
\cline { 3 - 7 } & & 8 & $72.9-100$ & $92.8 \mathrm{~b} \pm 6.7$ & $69.6-100$ & $96.4 \mathrm{ab} \pm 7.9$ \\
\hline
\end{tabular}

*The different letters in columns indicate significant differences between means (Kruskal - Wallis test, $\mathrm{p}<0.05$ ).

Data of amitraz efficacy (E\% and C\%) were transformed by $\operatorname{ArcSin}(\mathrm{x})$.

Table 6 . Comparison of the treatment efficacy (E\%) among experimental colonies with varied amount of brood area in 2011 and 2012 and between both years

\begin{tabular}{|c|c|c|c|c|c|c|}
\hline \multirow{3}{*}{ Year } & \multirow{3}{*}{$\begin{array}{c}\text { Number } \\
\text { of bee } \\
\text { colonies } \\
\text { (n) }\end{array}$} & \multirow{3}{*}{$\begin{array}{l}\text { Brood area } \\
\quad\left(\mathrm{dm}^{2}\right)\end{array}$} & \multicolumn{4}{|c|}{ Efficacy of amitraz } \\
\hline & & & \multicolumn{2}{|c|}{ After 6 weeks treatment } & \multicolumn{2}{|c|}{ After 8 weeks treatment } \\
\hline & & & $\begin{array}{c}\text { Range } \\
(\min -\text { max })\end{array}$ & Average $\pm \mathrm{SD}$ & $\begin{array}{c}\begin{array}{c}\text { Range } \\
\text { (min-max) }\end{array} \\
\end{array}$ & Average \pm SD \\
\hline \multirow{2}{*}{2011} & 22 & $\begin{array}{c}\text { To } 60 \mathrm{dm}^{2} \\
\text { Average }=51.3 \mathrm{dm}^{2}\end{array}$ & $88.2-100$ & $96.3 c^{*} \pm 3.5$ & $92.5-100$ & $98.0 c \pm 2.3$ \\
\hline & 22 & $\begin{array}{c}\text { Above } 60 \mathrm{dm}^{2} \\
\text { Average }=69.6 \mathrm{dm}^{2} \\
\end{array}$ & $67.4-98.9$ & $89.8 b \pm 8.6$ & 79.7 - 99.4 & $94.9 b \pm 4.7$ \\
\hline \multirow{2}{*}{2012} & 30 & $\begin{array}{c}\text { To } 60 \mathrm{dm}^{2} \\
\text { Average }=45.3 \mathrm{dm}^{2} \\
\end{array}$ & $79.1-98.6$ & $91.1 \mathrm{~b} \pm 5.8$ & $82.7-100$ & $95.0 \mathrm{~b} \pm 4.3$ \\
\hline & 15 & $\begin{array}{c}\text { Above } 60 \mathrm{dm}^{2} \\
\text { Average }=70.5 \mathrm{dm}^{2}\end{array}$ & $58.5-98.9$ & $82.5 a \pm 11.9$ & $72.9-99.3$ & $88.4 \mathrm{a} \pm 8.4$ \\
\hline
\end{tabular}

*The different letters in columns indicate significant differences between means

(Kruskal - Wallis test, $\mathrm{p}<0.05$ )

Data of amitraz efficacy (E\%) were transformed by $\operatorname{ArcSin}(\mathrm{x})$.

significantly between the experimental and the control group, whereas during last 3 weeks significantly higher number of mites died in the untreated colonies.

The tendencies of the number of dead parasites dynamics during the 8-week treatment with amitraz, were similar in both years. However, in both years, the highest numbers of mites died during the first 3 weeks of treatment. The numbers of parasites that died during the first 3 weeks made, on average, 79.9 and $74.9 \%$ of all mites that died during the 8 -week treatment with Biowar 500 strips, respectively, for 2011 and 2012 (Fig. 2).
The average weekly percentages of dead parasites collected from the experimental colonies significantly differed from the average percentages of dead parasites found in the untreated colonies. During the 8 -week treatment with strips containing amitraz, the $V$. destructor population decreased, on average, by $94.6 \%$ in relation to the total number of mites found in the colonies. As a result of the natural mortality in the control colonies, the population of parasites lowered only by $23.9 \%$ during the 8 week period (Fig. 3). 
The efficacy of amitraz in eliminating Varroa mites achieved after each week of the exposure to Biowar 500 strips in both years, is shown on the Figure 4.

The recommended (according to the producers directions for use) period of treatment with Biowar 500 strips is 6 to 8 weeks. The efficacy of the preparation $(\mathrm{E} \%)$ after 6 and 8 weeks of treatment, differed significantly in both years $\left(\mathrm{H}_{3,178}=34.80\right.$, $\mathrm{p}=0.000)$ (Tab. 5). Significantly higher numbers of parasites died after 8 weeks of treatment than after 6 weeks, both in 2011 and 2012. In 2011, the preparation's efficacy after 6 and 8 weeks was significantly higher than in 2012 . When the mites natural mortality was included, the efficacy against Varroa mites of the strips containing amitraz $(\mathrm{C} \%)$ was even higher. In addition, the 6- and 8-week preparation efficacies for 2011 and 2012 were similar $\left(\mathrm{H}_{3,178}=17.81, \mathrm{p}=0.0005\right)$.

The average efficacy of amitraz (E\%) calculated for the two years combined, after 6 and 8 weeks of treatment, was significantly different and amounted to $90.6 \%$ and $94.6 \% \quad\left(\mathrm{U}_{89,89}=2628.5\right.$, $\mathrm{p}=0.0001)$, respectively. The average efficacy of Biowar 500 assessed including the mites natural mortality $(\mathrm{C} \%)$ was similar and amounted to $94.7 \%$ and $96.9 \%$ $\left(\mathrm{U}_{89,89}=2609.5, \mathrm{p}=0.0008\right)$, respectively.

Negative correlation between the efficacy of the strips containing amitraz and the amount of brood in colonies (combined from the 3 measurements) was found. The value of the coefficient $r_{s}$ for the 6- and 8 -week treatment period in 2011 , amounted to: $r_{s}=-0.64(d f=43, p=0.000)$ and $r_{s}=-0.61(d f=43, p=0.000)$, respectively; and in 2012: $r_{s}=-0.36(d f=44, p=0.016)$ and $r_{s}=-0.40(d f=44, p=0.006)$, respectively.

The analysis of the treatment efficacy $(\mathrm{E} \%)$ between colonies with brood area (combined from the 3 measurements) less than $60 \mathrm{dm}^{2}$ and more than $60 \mathrm{dm}^{2}$, showed significant differences in the individual years (6-week treatment, $\mathrm{H}_{389}=25.49$, $\mathrm{p}=0.000 ; 8$-week treatment, $\mathrm{H}_{3,89}=24.55$, $\mathrm{p}=0.000)$, (Tab. 6). For the 6-week treatment, the lowest efficacy $(82.5 \%)$ was found in 2012, in the group of colonies with more than $60 \mathrm{dm}^{2}$ of brood area. The highest efficacy $(96.3 \%)$ was found in the group of colonies with less than $60 \mathrm{dm}^{2}$, in 2011. Similar relations were found when the 8-week treatment was analyzed.

Amitraz effectiveness does not depend on the strength of bee colonies (number of combs covered by bees) measured before, and after 3 and 6 weeks of the treatment $\left(\mathrm{r}_{\mathrm{s}}=0.15, \mathrm{df}=88, \mathrm{p}=0.14 ; \mathrm{r}_{\mathrm{s}}=0.08\right.$, $\mathrm{df}=88, \mathrm{p}=0.42$ and $\mathrm{r}_{\mathrm{s}}=0.05, \mathrm{df}=88$, $\mathrm{p}=0.62$, respectively).

No correlation was found between the level of infestation with Varroa mites and the efficacy of the treatment (for 2011, $r_{s}=0.18, d f=43, p=0.23$ and $r_{s}=0.26$; for 2012, $\left.\mathrm{r}_{\mathrm{s}}=0.18, \mathrm{df}=44, \mathrm{p}=0.08\right)$.

\section{DISCUSSION}

The assessment of the amitraz efficacy in fighting the Varroa mite showed amitraz high but variable efficacy after 6-week and 8-week treatments (according to the manufacturer recommendations, the preparation should stay in the colony for 6 to 8 weeks). It has been noted for both years that the treatment extended to 8 weeks gave better results. During the last two weeks of the treatment (the total for the $7^{\text {th }}$ and the $8^{\text {th }}$ week), in some colonies even over 100 mites had fallen. Keeping the miticide in the colonies for 8 weeks resulted in a significant increase of the amitraz efficacy; on average, by $4 \%$. In the untreated colonies, during 6 weeks only $16.4 \%$ of mites died due to the natural mortality, and $23.9 \%$ during 8 weeks.

The field studies of the efficacy of the strips containing $400 \mathrm{mg}$ of amitraz (Biowar) that was conducted in 2004 - 2007 in the Polish apiaries, showed considerably higher variability. In 2004, the strips were inserted into the colonies in the $3^{\text {rd }}$ decade of August. After 6 weeks of the treatment, the mite population decreased, on average, by $89.1 \%$ (with the efficacy between 28.7 and $100 \%$ ). In 2005, the treatment started on three different dates (the $3^{\text {rd }}$ decade of August, 1st decade of September, and 
$3^{\text {rd }}$ decade of September). After a 6-week treatment, the following percentages of the Varroa mite had fallen: 74.8, 81.7, and $67.4 \%$, respectively (Pohorecka et al., 2006). However, the studies conducted by Chuda-Mickiewicz et al. (2007) showed the average of $87.8 \%$ of fallen mites (between 51.2 and 96.3\%), already after 5 weeks of the treatment. The estimation of the amitraz efficacy in the apiaries located in different, climatically diversified, regions of Poland, also showed variable amitraz efficacy (the strips were inserted on the same date, for 6 weeks). In the groups of colonies treated from the $1^{\text {st }}$ decade of August, the efficacy amounted to $69.2,92.4$, and $96.2 \%$. The treatment that started in the $3^{\text {rd }}$ decade of August resulted in higher efficacy in all apiaries, amounting to 96.6, 97.6, and 97.3\%, respectively (Londzin et al., 2007). Semkiw et al. (2008) also placed the strips in the colonies in the $3^{\text {rd }}$ decade of August and noted a significant decrease in the mite population already after 6 weeks (on average, by 94.0\%). The studies showed also the increase in the amitraz efficacy by $2.6 \%$ after extending the treatment to 8 weeks.

The strips containing $500 \mathrm{mg}$ of amitraz (preparation Apivar) are widely spread in the control of the Varroa mites in a lot of countries, not only in Europe. The results of the assessments of this preparation's efficacy were also highly variable. A year after the registration of Apivar in Italy, the preparation efficacy was, on average, $83.8 \%(78.8-87.3 \%)$ after 6 weeks of treatment (Floris et al., 2001). In France, where the preparation has been used for the longest time (since 1995), Faucon et al. (2007) and Vallon et al. (2007) estimated Apivar's efficacy to be on the level of 99.5 and $98.4 \%$, respectively. In $17 \%$ of the colonies examined in Portugal, the Apivar efficacy did not exceed $60.1 \%$ (Pires et al., 2005).

The above-cited results do not allow to draw explicit conclusions on the causes of the variability of the amitraz strips efficacy. The final therapeutic effect can be conditioned by several factors which were not analyzed in the above-mentioned studies. The active substance dosage acting on the Varroa mites through the adult bees, is of decisive importance. Thus, not only the amount of amitraz contained in the strips but also bees' activity, influences the amount of the active substance that will appear on the surface of the bees' bodies. The external temperature does not influence directly the amitraz release from the strips but it has an impact on the biology (activity) of the honeybee colonies. Thus, not only the date of conducting the treatment but also the treatment duration and atmospheric conditions can influence the amitraz efficacy in fighting the parasites. Supplementing the winter reserves during the treatment can additionally stimulate the bees to higher activity and contribute to the increase in the treatment efficacy.

In our studies, the amitraz efficacy in 2011 was significantly higher than in 2012 despite the fact that the level of $V$. destructor infestation in 2011 was also considerably higher than in 2012. In both years, the treatments were conducted on the same date and in colonies of similar strength (the number of combs covered by bees and the brood area). The only factor that differed in 2011 and 2012 was the external temperature. The average temperature in September of 2011 and 2012 was similar and amounted to $14.5^{\circ} \mathrm{C}$ and $13.0^{\circ} \mathrm{C}$, respectively. However, in October 2011, the average monthly temperature was $13.0{ }^{\circ} \mathrm{C}$ - two times higher than in October 2012.

It cannot be excluded that the reason for the variability in the efficacy of amitraz could have been the emergence of a mite population less susceptible to amitraz in the colonies in which lower treatment efficacy was noted. The laboratory assessment of amitraz activity against Varroa mites showed that in some mite populations originating from the bee colonies that had been treated with amitraz for 5 years, the mean lethal time (MLT) was extended in comparison to the populations from the colonies treated for 5 years with fluvalinate 
(Pohorecka and Bober, 2008). In those studies, significant variability of the level of susceptibility to amitraz between the mite populations originating from different colonies in the same apiary was noted. In laboratory conditions, significant lethal concentration $\left(\mathrm{LC}_{50}\right)$ differences were detected between resistant and susceptible mites from Argentinean apiaries (Maggi et al., 2010).

The possibility of using the amitraz strips in the colonies containing brood is clearly an advantage. Additionally, releasing the active substance for a long time allows amitraz to act on the successive parasite generations developing with the emergence of young bees. The results showed that the amount of brood present in the colony during the treatment significantly influences the efficacy in fighting the $V$. destructor infestation. In both years, the percentage of the mites killed by amitraz was significantly higher in the colonies containing up to $60 \mathrm{dm}^{2}$ of brood in comparison to the colonies with more than $60 \mathrm{dm}^{2}$ (96.3 and $92.3 \%$, respectively, for the two years combined). The high number of young bees makes it possible for the mites to forage on the specimens that did not have contact with the amitraz and the presence of brood provides new generations of bees. Similar correlation can be noticed in the results of Chuda-Mickiewicz et al. (2008). In the colonies treated with the amitraz strips (400 $\mathrm{mg} / \mathrm{strip}$ ) for 8 weeks, the queens were isolated in cages made from the queen excluders at the beginning of the third (group I) and the sixth (group II) week of the treatment. The treatment efficacy was very high and amounted to 99.3 and $99.1 \%$, respectively, for groups I and II.

\section{CONCLUSIONS}

Using the amitraz to control the $V$. destructor infestation for a lot of years in the Polish apiaries did not lead to the significant decrease of this substance efficacy in fighting the mites. The amitraz strips (500 $\mathrm{mg}$ active substance/strip) allow to considerably decrease the mite population in the honeybee colonies.

Extending the treatment to 8 weeks significantly increases the treatment efficacy.

To assure full protection of the honeybee colonies, the use of amitraz strips should be incorporated into the year-long Varroa management.

\section{REFERENCES}

Abbott W. S. (1925) - A method of computing the effectiveness of an insecticide. J. Econ. Entomol.,18:265-267.

Anderson D. L., Trueman J. W. H (2000) Varroa jacobsoni (Acari: Varroidae) is more than one species. Exp. and Appl. Acarol., 24:165-189. DOI:10.1023/A:1006456720416.

BN-81/9148-01 (1982) - Norma Branżowa - Rodzina pszczela. [Polish Industry Standard - Honeybee colony] - Dziennik Normalizacji i Miar Nr 19/1981, poz. 77. Wydawnictwo Normalizacyjne Warszawa, p. 6.

Boecking O., Genersch E. (2008) Varroosis - the ongoing crisis in beekeeping. J. Verbrauch. Lebensm., 3: 221-228. DOI: 10.1007/s00003-008-0331-y.

Bogdanov S., Kilchenmann V. (1995) - Acaricide residues in beeswax: long-term studies in Switzerland. Apidologie, 26(4): 319321.

Bogdanov S., Kilchenmann V., Imdorf A (1998) - Acaricide residues in some bee products. J. Apic. Res., 37(2): 57-67.

Brodschneider R., Moosbeckofer R., Crailsheim K. (2010) - Surveys as a tool to record winter losses of honey bee colonies: a two year case study in Austria and South Tyrol. J. Apic. Res., 49: 23-30. DOI:10.3896/ IBRA.1.49.1.04.

Chauzat M. P., Carpentier P., Madec F., Bougeard S., Cougoule N., Drajunel P., Clement M. C., Aubert M., Faucon J. P. (2010) - The role of infectious agents and parasites in the health of honey bee colonies in France. J. Apic. Res., 49:31-39. DOI:10.3896/IBRA.1.49.1.05. 
Chuda-Mickiewicz B., Prabucki J., Samborski J., Rostecki P. (2007) Evaluation of varroacidal efficacy of Biowar preparation. J. Apic. Sci., 51(2): 47-53.

Chuda-Mickiewicz B., Prabucki J., Samborski J., Rostecki P. (2008) Skuteczność zwalczania Varroa destructor paskami z amitrazą w rodzinach z czerwiem. [The effectiveness of amitraz strips in control of Varroa destructor in honeybee colonies with brood]. In Materiaty z XLV Naukowej Konferencji Pszczelarskiej, Puławy, Poland, 11-12 marca, 2008, pp. 77-79.

Commission of the European Communities (2002) - Concerted Action 3686: "Coordination in Europe of research on integrated control of Varroa mites in honey bee colonies". Technical guidelines for the evaluation of treatments for control of Varroa mites in honey bee colonies. Recommendations from the CA3686. Document prepared during discussions within the CA3686 working group: "Evaluation of treatment for control of Varroa mites in honey bee colonies".

Commission Regulation (EU) No 37/2010 of 22 December 2009 on pharmacologically active substances and their classification regarding maximum residue limits in foodstuffs of animal origin. Dz. U. L15 z 20.1.2010.

Dahle B. (2010) - The role of Varroa destructor for honey bee colony losses in Norway. J. Apic. Res., 49: 124-125. DOI: 10.3896/IBRA.1.49.1.26.

Delaplane K. S. (2011) - Integrated pest management in Varroa, in Carreck $\mathrm{N}$. L.(Ed.) Varroa - still a problem in the $21^{\text {st }}$ Century? International Bee Research Association, Cardiff, pp. 43-51.

Dujin T., Jovanovic V., Suvakov D., Milkovic Z. (1991) - Effect of using amitraz preparations for several years on the development of resistant strains of Varroa jacobsoni. Veterinarski Glasnik, 45(11-12): 851-855.

Elzen P. J., Baxter J. R., Spivak M., Wilson W. T. (1999) - Amitraz resistance in Varroa: new discovery in North America. Am. Bee J., 139(5): 362.
Elzen P. J., Baxter, J. R., Spivak M., Wilson W. T. (2000) - Control of Varroa jacobsoni Oud. resistant to fluvalinate and amitraz using coumaphos. Apidologie, 31: 437-441.

Evans P. D., Gee J. D. (1980) - Action of formamidine pesticides on octopamine receptors. Nature, 28: 60-62.

Genersch E. (2010) - Honey bee pathology: current threats to honey bees and beekeeping. Appl. Microbiol. Biotechnol., 87: 87-97.

Genersch E., von der Ohe W., Kaatz H-H., Schroeder A., Otten C., Büchler R., Berg S., Ritter W., Mühlen W., Gisder S., Meixner M., Liebig G., Rosenkranz P. (2010) - The German bee monitoring project: a long term study to understand periodically high winter losses of honey bee colonies. Apidologie, 41: 332-352.

Guzmán-Novoa E., Eccles L., Calvete Y., Mcgowan J., Kelly P. G, Correa-Benitez A. (2010) - Varroa destructor is the main culprit for the death and reduced populations of overwintered honey bee (Apis mellifera) colonies in Ontario, Canada. Apidologie, 41: 443-450. DOI: 10.1051/apido/2009076.

Federal Register/Vol. 78, No. 54/Wednesday, March 20, 2013/Rules and Regulations

Floris I., Sattaa A., Garaub V. L., Melisb M., Cabrasb P., Aloulc N. (2001)Effectiveness, persistence, and residue of amitraz plastic strips in the apiary control of Varroa destructor. Apidologie, 32: 577-585.

Faucon J. P., Drajnudel P., Chauzat M. P., Aubert M. (2007) - Contrôle de l'efficacité du médicament APIVAR ND contre Varroa destructor, parasite de l'abeille domestique. Revue Méd. Vét., 158(6): 283-290.

Jimenez J., Bernal J., de Nozal M., Toribio L. (1997) - Characterisation and monitoring of amitraz degradation products in honey. J. High Resolut. Chrom., 18: 81-84.

Johnson R. M., Ellis M. D., Mullin C. A., Frazier M. (2010) Pesticides and honey bee toxicity - U.S.A. Apidologie, 41(3): 312-331. 
Johnson R. M., Dahlgren L., Siegfried B. D., Ellis M. D. (2013) - Acaricide, Fungicide and Drug Interactions in Honey Bees (Apis mellifera). PLoS ONE, 8(1): e54092. DOI:10.1371/journal.pone.0054092.

Korta E., Bakkali A., Berrueta L. A., Gallo B., Vicente F., Kilchenmann V., Bogdanov S. (2001) - Study of acaricide stability in honey. Characterization of amitraz degradation products in honey and beeswax. J. Agric. Food Chem., 49: 5835-5842.

Le Conte Y., Ellis M. D., Ritter W. (2010) - Varroa mites and honey bee health: can Varroa explain part of the colony losses? Apidologie, 41: 353-363. DOI: 10.1051/ apido/2010017.

Lodesani M., Pellacani A., Bergomi S., Carpana E., Rabitti T., Lasagni P. (1992) - Residue determination for some products used against Varroa infestation in bees. Apidologie, 23(3): 257-272.

Lodesani M., Colombo M., Spreafico M. (1995) - Ineffectiveness of Apistan treatment against the mite Varroa jacobsoni Oud in several districts of Lombardy (Italy). Apidologie, 26(1): 67-72.

Londzin W., Pohorecka K., ChudaMickiewicz B. (2007) - Skuteczność Biowaru i wybranych leków warroabójczych na podstawie badań terenowych przeprowadzonych w 2006 roku. [Field studies on the effectiveness of Biowar and other varroacidal formulations in 2006]. In Materiaty z XLIV Naukowej Konferencji Pszczelarskiej, Pulawy, Poland, 24-25 kwietnia, 2007, pp. 72-74.

Maggi M. D., Ruffinengo S. R., Negri P., Eguaras M. J. (2010)-Resistance phenomena to amitraz from populations of the ectoparasitic mite Varroa destructor of Argentina. Parasitol. Res., 107(5): 1189-92. DOI: 10.1007/s00436-010-1986-8.

Martel A. C., Zeggane S., Aurières C., Drajnudel P., Faucon J. P., Aubert M. (2007) - Acaricide residues in honey and wax after treatment of honey bee colonies with Apivar or Asuntol 50. Apidologie, 38: 534-544.
Mathieu L., Faucon J. P. (2000) - Changes in the response time for Varroa jacobsoni; exposed to amitraz. J. Apic. Res.; 39(3-4): 155-158.

Martin S. J., Highfield A. C., Brettell L., Villalobos E. M., Budge G. C., Powell M., Nikaido S., Schroeder D. C. (2012) - Global honey bee viral landscape altered by a parasitic mite. Science, 336: 1304-1306. http://dx.doi. org/10.1126/science.1220941.

Merrington O. (1990) - Bibliography on the use of amitraz for Varroa control in bees (Apis spp.) (1979-1989). Cambridge Animal and Public Health Ltd., Cambridge, p 36.

Milani N. (1999) - The resistance of Varroa jacobsoni Oud. to acaricides. Apidologie, 30(2-3): 229-234.

Mullin C. A., Frazier M., Frazier J. L., Ashcraft S., Simonds R. (2010) - High levels of miticides and agrochemicals in North American apiaries: implications for honey bee health. PLoS ONE, 5(3): e9754. DOI:10.1371.

Nazzi F., Brown S.P., Annoscia D., Del Piccolo F., Di Prisco G., Varricchio P., Della Vedova G., Cattonaro F., Caprio E., Pennacchio F. (2012) - Synergistic Parasite-Pathogen Interactions Mediated by Host Immunity Can Drive the Collapse of Honeybee Colonies. PLoS Path., 8(6): e1002735. doi:10.1371/journal.ppat.1002735.

Pires S., Pereira Ó., Murilhas A. (2007) - Field and laboratory testing for amitraz-tolerant varroa populations. How comparable are their results? In Proceedings of $40^{\text {th }}$ Apimondia International Apicultural Congress. Melbourne, [online] http://hdl. handle.net/10198/5094

Pires S., Murilhas A., Pereira O., Maia M. (2005) - Current effectiveness of amitraz against Varroa in Portugal. In Proceedings of $39^{\text {th }}$ Apimondia International Apicultural Congress, Dublin, Irlandia, 2005: 78. 
Pohorecka K., Bober A. (2008) - Porównanie wrażliwości na amitraz populacji Varroa destructor pochodzących z pasiek leczonych amitrazem i fluwalinatem. [Amitraz sensitivity of Varroa destructor populations from apiaries treated with amitraz and fluwalinat]. In Materiaty z XLV Naukowej Konferencji Pszczelarskiej, Puławy, Poland, 11-12 marca, 2008, pp. 83-85.

Pohorecka K., Bober A., Skubida M., Zdańska D. (2011) - Epizootic status of apiaries with massive losses of bee colonies (2008-2009). J. Apic. Sci., 55(1): 137-150.

Pohorecka K., Bieńkowska M., Gerula D., Semkiw P., Skubida P. (2006) - Effect of biological factors on anti-varroa efficacy of Biowar formula. In Materiaty $z$ XLIII Naukowej Konferencji Pszczelarskiej, Puławy, 25-27 kwietnia, 2006, pp. 139-140.

Potts S. G., Roberts S. P. M., Dean R., Marris G., Brown M., Jones R., Settele J. (2010) - Declines of managed honeybees and beekeepers in Europe. J. Apic. Res., 49(1): 15-22 DOI 10.3896/ IBRA.1.49.1.02.

Rosenkranz P., Aumeier P., Ziegelmann B. (2010) - Biology and control of Varroa destructor. J. Inv. Path., 103: S96-S119. [online] http://dx.doi.org/10.1016/j. jip.2009.07.016.

Schäfer M. O., Ritter W., Pettis J. S., Neumann P., (2010) - Winter losses of honey bee colonies (Apis mellifera): The role of infestations with Aethina tumida and Varroa destructor. J. Econ. Ent., 103: 10-15. [online] http://dx.doi.org/10.1603/EC09233.
Semkiw P., Pohorecka K., Skubida P. (2008) - Skuteczność warroabójcza Biowaru, Baywarolu i kwasu szczawiowego w badaniach terenowych w 2007 roku. [Field studies on the varroacidal efficacy of Biowar, Bayvarol and oxalic acid in 2007]. In Materiaty z XLV Naukowej Konferencji Pszczelarskiej, Puławy, Poland, 11-12 marca, 2008, pp. 81-83.

Spreafico M., Eördegh F. R., Bernardinelli I., Colombo M. (2001) First detection of strains of Varroa destructor resistant to coumaphos. Results of laboratory test and field trials. Apidologie, 32: 49-55.

Topolska G., Gajda A., Pohorecka K., Bober A., Kasprzak S., Skubida M., Semkiw P. (2010) - Winter colony losses in Poland. J. Apic. Res., 49: 126-128 [online] http://dx.doi.org/10.3896/IBRA.1.49.1.27.

Wallner K. (1999) - Varroacides and their residues in bee products. Apidologie, 30(2-3): 235- 248.

Vallon J., Savary F., Jourdan P. (2007) - Suivi de l'efficacité des traitements contre Varroa destructor bénéficiant d'une AMM au cours de l'automne et l'hiver 2006/2007. Bull Tech Apic. 34(2): 49-54.

van Engelsdorp D., Hayes Jr. J., Underwood R. M., Caron D., Pettis J. (2011) - A survey of managed honey bee colony losses in the USA, fall 2009 to winter 2010. J. Apic. Res., 50: 1-10. DOI 10.3896/ IBRA.1.50.1.0. 


\title{
SKUTECZNOŚĆ ZWALCZANIA \\ ROZTOCZY VARROA DESTRUCTOR PASKAMI Z AMITRAZEM PO WIELOLETNIM STOSOWANIU TEJ SUBSTANCJI W PASIEKACH
}

\author{
Semkiw P., Skubida P., Pohorecka K.
}

S t r e s $z$ c $z$ e $n$ i e

Celem badań była ocena skuteczności amitrazu (preparat Biowar 500, Biowet Puławy, $500 \mathrm{mg}$ substancji czynnej/pasek) w zwalczaniu Varroa destructor w rodzinach pszczelich.

Badania polowe wykonano w 2011 i 2012 roku, w pasiece Oddziału Pszczelnictwa Instytutu Ogrodnictwa w Puławach. Rodziny pszczele rasy Apis mellifera caucasica osadzone były w ulach wielkopolskich, wyposażonych w wysokie osiatkowane dennice z szufladkami umożliwiającymi monitorowanie osypu pasożytów $V$. destructor. Skuteczność warroabójczą amitrazu oceniono ogółem w 89 rodzinach doświadczalnych, a naturalną śmiertelność pasożyta oceniono w 10 rodzinach kontrolnych (nieleczonych). W obydwu latach badań paski preparatu zostały umieszczone $\mathrm{w}$ rodzinach doświadczalnych $\mathrm{w}$ ostatnim tygodniu sierpnia i usunięte po 8 tygodniach (w tym czasie rodziny kontrolne nie były leczone). Paski zawieszono w przestrzeniach między ramkowych (poszerzonych do $16 \mathrm{~mm}$ ) po obu stronach gniazda, centralnie, pomiędzy dwoma ostatnimi plastrami, na których znajdował się czerw. Martwe pasożyty osypane na dno uli w rodzinach doświadczalnych i kontrolnych liczono co 7 dni. Po usunięciu pasków w rodzinach obydwu grup wykonano kontrolne zabiegi lecznicze w celu oszacowania liczby roztoczy które przeżyły. Wszystkie rodziny odymiono dwukrotnie co 7 dni preparatem Apiwarol (12,5 mg amitrazu/tabletkę) w dawce 1 tabletka/zabieg/ rodzinę, a w pierwszym tygodniu listopada (brak czerwiu krytego) dodatkowo zastosowano 3,5\% roztwór kwasu szczawiowego w syropie cukrowym, w formie nakrapiania na pszczoły w uliczkach między ramkowych $(5 \mathrm{ml}$ roztworu/uliczkę). Po każdym zabiegu kontrolnym martwe pasożyty liczono po 7 dniach od zastosowania preparatu.

Poziom inwazji $V$. destructor $\mathrm{w}$ rodzinach pszczelich różnił się istotnie w poszczególnych latach i wynosił średnio 550,1 pasożytów/rodzinę w 2011 roku i 436 pasożytów/rodzinę w 2012 roku. Liczba pasożytów w poszczególnych rodzinach była pozytywnie skorelowana $\mathrm{z}$ ilością wychowywanego przez nie czerwiu. W rodzinach kontrolnych (nieleczonych) poziom inwazji roztoczy był istotnie wyższy i wynosił średnio 1020,6 pasożytów. Podczas 8 tygodniowego okresu leczenia paskami z amitrazem populacja $V$. destructor zmniejszyła się średnio o 94,6\% w stosunku do całkowitej liczby roztoczy, natomiast w rodzinach kontrolnych populacja pasożytów zmniejszyła się w tym okresie jedynie o $23,9 \%$. W obydwu latach skuteczność warroabójcza preparatu uzyskana po 6 i 8 tygodniowym okresie leczenia różniła się istotnie. Obecność pasków w rodzinach pszczelich przez okres 6 tygodni spowodowała obniżenie populacji roztoczy średnio o 93,1 i 88,3\% natomiast po 8 tygodniach o 96,5 i 92,8\% (odpowiednio dla lat 2011 i 2012). Średnia skuteczność amitrazu wyliczona łącznie dla dwóch lat wyniosła po 6 i 8 tygodniach leczenia odpowiednio $90,6 \%$ i 94,6\%, natomiast przy uwzględnieniu naturalnego osypu roztoczy średnia skuteczność preparatu była wyższa i wyniosła odpowiednio 94,7\% i 96,6\%. Ogólna ilość czerwiu obecnego w rodzinach podczas zabiegów leczniczych miała istotny wpływ na skuteczność warroabójczą zastosowanego preparatu.

Słowa kluczowe: Varroa destructor, zwalczanie, rodziny pszczele, paski z amitrazem, skuteczność. 